Review

\title{
Ginseng on Hyperglycemia: Effects and Mechanisms
}

\author{
John Zeqi Luo ${ }^{1}$ and Luguang Luo ${ }^{2}$
}

${ }^{1}$ PLME Department of Medicine, Brown University, Providence, RI 02912 and ${ }^{2}$ The Center for Stem Cell Biology, Department of Research, Roger Williams Hospital, Providence RI 02908, USA

It has been reported that American ginseng attenuates hyperglycemia and may present itself as a supplement to diabetes therapy. However, the lack of standardization in the usage of ginseng root leads to inconclusive results when applied to diabetes treatment. The mechanisms of American ginseng root in the treatment of diabetes remains a mystery. This greatly limits the effective utilization of American ginseng in facilitating diabetic therapy. Initiating studies have shown that American ginseng increases insulin production and reduces cell death in pancreatic $\beta$-cells. Also, studies have revealed American ginseng's ability to decrease blood glucose in type II diabetes patients as well as in streptozotocin-induced diabetic animals (STZ-diabetic mice). These data suggest that effects of ginseng in improving hyperglycemia may alter mitochondrial function as well as apoptosis cascades to ensure cell viability in pancreatic islet cells. This review briefly summarizes current knowledge of ginseng components and clinical studies related to diabetes. Further research will be needed to explore and identify the component(s) of ginseng, which may be responsible for the beneficial effects observed in animal studies which could then be extrapolated to human islets.

Keywords: ginseng-blood glucose-STZ diabetic animals-apoptosis-UCP-2

\section{Introduction}

Due to a 3 -fold increase in the consumption of herbal remedies in the United States along with a staggering popularity of the ginseng herb as a method of sustaining good health, significant focus have been placed on two widely used types of ginseng, American (Panax quinquefolius L.) (1) and Asian ginseng (Panax ginseng CA Meyer) (2-4). The usage of ginseng root for medicinal purposes have been recorded for millennia, known as a tonic capable of sustaining longevity as well as maintaining viability $(5,6)$. The two species display different effects, possibly due to the different active chemical makeup of each other. Asian ginseng is said to facilitate blood flow, alleviate fatigue as well as relieve oxidative stress in diabetic conditions through various mechanisms such as the inhibition of

For reprints and all correspondence: Dr Luguang Luo, The Center for Stem Cell Biology, Department of Research, Roger Williams Hospital, Boston University, Medical School, 825 Chalkstone Avenue,

Providence, RI 02908, USA. Tel: +1-401-456-5344; Fax: +1-401-4565759; E-mail: Lluo@rwmc.org

C 2008 The Author(s).

This is an Open Access article distributed under the terms of the Creative Commons Attribution Non-Commercial License (http://creativecommons.org/ licenses/by-nc/2.0/uk/) which permits unrestricted non-commercial use, distribution, and reproduction in any medium, provided the original work is properly cited. lipid peroxidation (7) (Table 1). American ginseng has been reported to have stress-relieving qualities, anti-aging effects and aids in digestion (3). Clinical studies have reported that ginseng improves psychological function, immune function and conditions associated with diabetes (8). Ginseng root has been reported to treat diabetic symptoms in the Compendium of Materia Medica (Ben Cao Gang Mu) by Dr Li (Li, ShiZhen, Ming Dynasty from 1368 to 1644, in China). This is the most complete and comprehensive pre-moderm herbal textbook. The symptom was called Xiao Ke described as over eating, drinking and losing energy, body weight which are typical diabetic symptoms in modern medicine. Common methods of treatment for hyperglycemia (high glucose) include both mono-therapy and combination therapy with insulin, metformin, rosiglitazone and acarbose. These treatments have been shown to help control blood glucose levels but do not solve the problemno pancreatic $\beta$-cell function, which results in numerous diabetic complications (9). Developmental information shows American ginseng may correct hyperglycemia. 
Table 1. Differing effects of American and Asian ginseng

\begin{tabular}{ll}
\hline $\begin{array}{l}\text { American ginseng } \\
\text { (Panax quinquefolius L.) }\end{array}$ & $\begin{array}{l}\text { Asian ginseng } \\
\text { (Panax ginseng CA Meyer) }\end{array}$ \\
\hline $\begin{array}{l}\text { Differing Effects } \\
\text { Anti-aging effects } \\
\text { (human, rat) }(37,38)\end{array}$ & $\begin{array}{c}\text { Increases blood flow } \\
\text { (human) }(13,39)\end{array}$ \\
$\begin{array}{l}\text { Anti-hyperglycemia } \\
\text { (human, mice) }(3,4,40,41)\end{array}$ & $\begin{array}{c}\text { Decreases fatigue } \\
\text { (human) }(13,42)\end{array}$ \\
Aids in digestion (rat) (43) & $\begin{array}{c}\text { Stimulates nervous system } \\
\text { (rat, cell) }(2,44)\end{array}$ \\
Reduces Stress (rat) (45) & $\begin{array}{c}\text { Anti-inflammatory agent } \\
\text { (cell) }(46-48)\end{array}$ \\
Enhances memory (rat) (49) & Liver-protection (rat)(50) \\
Reduces cholesterol (cell) (5) & Endurance (rat) (51) \\
Improves sexual function (rat) (52) & Anti-Depression (mice) (53) \\
\hline
\end{tabular}

\section{A Breakdown of Ginseng Components}

A range of chemical components of ginseng such as ginsenosides, alkaloids, polypeptides and polysaccharides has been identified with their biological activity. The elements Phosphorus (P), Potassium (K), Calcium (Ca), Thallium (Ti), Manganese $(\mathrm{Mn})$, Iron $(\mathrm{Fe})$, Copper $(\mathrm{Cu})$, Zinc $(\mathrm{Zn})$ and Strontium $(\mathrm{Sr})$ were detected by screening the components of ginseng (10). Other minor components include volatile oils (member of vitamin B complex), manganese, vanadium, copper, cobalt, fatty acids, amino acids, simple sugars and other carbohydrates (11). Aside from the basic elemental components of ginseng, glycosides have been reported to be the active component in ginseng responsible for ginseng's medicinal value. Glycoside is a naturally occurring substance consisting of a sugar and non-sugar moiety. A group of saponins (glycoside which produces froth by reducing water surface tension) in ginseng were named ginsenosides, and were classified into subclasses Ro, Ra, Rb, Rc, Rd, Re, Rf, Rg and Rh. These ginsenosides were differentiated based on their retention factor values in thin layer chromatography (TLC), which is the distance that the ginsenosides travel up the TLC column (12). More than 60 ginsenosides have been found in different parts of the ginseng plant (13). Asian ginseng can be distinguished from American using ginsenoside profiles since Asian and American ginseng contains various ginsenosides (14). A recent study analyzed the ginsenoside composition of Asian and American ginseng through observing 12 commercially available ginsenosides. Asian ginseng contains ginsenoside $\mathrm{Rf}$ (15) and $\mathrm{Rg} 2$, but American ginseng does not. Also, Rg1 content is over 10 -folds as compared with American ginseng. However, American ginseng contains twice the level of ginsenoside Re. (16).

Since the usage of ginseng root extracts lacks standardization due to the different levels of ginsenosides in different batches, purified ginsenosides have been used to test whether the effects of ginseng root lies on one ginsenoside or a combination of various ginsenosides. The anti-hyperglycemic effects of the total ginsenosides extracted from Asian ginseng were evaluated in diabetic $\mathrm{C} 57 \mathrm{BL} / 6 \mathrm{~J} \mathrm{ob} / \mathrm{ob}$ mice. Total ginsenosides had significant anti-hyperglycemic and anti-obesity properties in a diabetic ob/ob mouse model (17). In the same model, Ginsenoside Re showed to improve muscle metabolism and reduce inflammation through increase C-reactive protein levels, leading to an anti-hyperglycemic effect (18). Ginsenoside $\mathrm{Rh} 2$ was able to lower plasma glucose in STZ-diabetic rats in a dosage dependent manner (19). Rh2 has also been noted to have the ability to regulate glucose by increasing insulin secretion through the control of nerve terminals, signifying that the effects of ginsenosides encompass the entire body (20). There were no reports of ginsenosides affecting pancreatic function in the mentioned studies. It is possible that ginsenoside components create an anti-hyperglycemic effect, which aids pancreatic function as well.

\section{Ginseng Aids the Normalization of Hyperglycemia}

There have been numerous reports of ginseng root (American and Asia ginseng) improving diabetic conditions in both humans as well as animal studies. In animal studies, orally administered ginseng root was able to counteract the effects of high-fructose induced insulin resistance in rats after 4 weeks, decreasing glucose concentrations, as well as inhibit insulin resistance (21). Ethanol extract of ginseng root prevented weight gain, fasting blood glucose, triglyceride and high free fatty acid levels in a highfat induced hyperglycemia mouse model (22). Ginsenoside Re reduced blood glucose levels, cholesterol and triglyceride levels as well as reduced oxidative stress in the eye and kidney of diabetic rats (2). Clinical studies have reported that American ginseng has the ability to lower blood glucose in diabetic patients. (3) In some cases, both type II diabetic patients and non-diabetic subjects showed to benefit from an intake of American ginseng in terms of stabilizing post-prandial glycemia after meals, suggesting that the intake of ginseng may also benefit healthy individuals. American ginseng did not have adverse effects on healthy individuals but rather beneficial effects in postprandial glycemia compared with placebo when administered together with the glucose challenge. In subjects with type II diabetes mellitus, significant reductions were observed when ginseng was taken $40 \mathrm{~min}$ before the glucose challenge (3). In both clinical and animal studies, ginseng root has shown to have the ability to improve hyperglycemia in diabetic conditions.

\section{Multiple Mechanisms Behind the Effects of Ginseng}

A limited amount of mechanism studies have been done on the effects of American ginseng on either the pancreas or 
any other organ. According to the mechanistic studies, which have been performed, ginseng root and components seem to exert its effect through several different mechanisms, suggesting that we have merely scraped the surface in discovering the effects of ginseng and its components. Studies have shown that ginseng and its components attenuate hyperglycemia in two ways, the first through enhancing pancreatic $\beta$-cell function and the other through reducing insulin resistance. This leads us to believe that ginseng may have benefits for both type I and type II diabetes.

American ginseng root extracts have been shown to affect pancreatic $\beta$-cells through altering cell metabolism, increasing insulin production and reducing apoptosis in a dosage dependent manner (23). Ginseng extracts were able to enhance ATP production and in turn increase insulin production, as insulin deficiency is often linked to a lack of ATP produced $(24,25)$. Along with an increase in ATP production, ginseng reduced mitochondrial protein UCP-2, which negatively regulates insulin secretion (13,25-28). Aside from affecting insulin production, ginseng may have the ability to target various glucose receptors, creating an antilipolytic effect, thus attenuating hyperglycemia $(12,29)$. This suggests that there exist other pathways through which ginseng acts through. Overall, ginseng is able to enhance insulin production through regulating cell metabolism.

Though UCP-2 regulates insulin secretion, it has also been reported to decrease cell longevity $(12,30)$. Apoptosis is one of the common causes of cell death in pancreatic $\beta$-cells. Resulting in the destruction of genetic material, apoptosis is regulated by factors such as Bcl-2, which protects against apoptosis and Caspase- $3 / 9$, which promotes death through the caspase cascade $(8,31,32)$. American ginseng reduces apoptosis by promoting caspase-3/9 and enhanced cell protective $\mathrm{Bcl}-2$ protein levels, resulting in protecting cells against apoptosis (23). Preventing apoptosis allows for further cell function and insulin production in pancreatic $\beta$-cells.

Aside from affecting cell metabolism and longevity, ginseng has the ability to change neuropeptide through $\mathrm{Rh} 2$, a ginsenoside derived from Panax ginseng, in STZ-diabetic rats. Rh2 lowered plasma glucose due to an increase in beta-endorphin secretion that activates opioid mu-receptors thereby resulting in an increased expression of GLUT 4, a glucose transporter in fat and muscle tissue (19). Protopanaxatriol, a ginsenoside metabolite, also increased GLUT4 and improved insulin resistance (33). The up-regulation of GLUT-4 signalizes that ginseng has an effect on fat/muscle tissue, possibly decreasing insulin resistance.

Along with mechanisms pertaining to specific organs and tissues, ginseng components have shown to have general affects as well. Ginsenoside Re prevented oxidative stress in (2) and reduce inflammation in STZ-diabetic rats (34). In cellular models, ginseng reduces $\mathrm{H} 2 \mathrm{O} 2$ induced oxidative damage and enhances superoxide dismutase and catalase to create a protective effect in a dosage dependent manner (1). Ginseng leaf and berry extracts also show high antioxidant activities which detoxify free radicals excessively produced in diabetic environments (35). Currently, studies show ginseng as having general anti-oxidative properties in specific cells and tissue such as pancreatic $\beta$-cells and fat/muscle tissue. We feel that there are many more undiscovered mechanisms which ginseng acts through.

\section{Controversies Around the Benefits of Ginseng on Diabetes}

The usage of herbs and spices has long been documented than modern pharmaceuticals. Unlike modern pharmaceuticals, which utilize small molecular weight compounds consumed in a purified form, herbs are eaten in combinations of unmeasured quantities. It is almost certain the herbs contain beneficial qualities and that the goal should not be to ask if they have effects but rather what effects do they have (36). Since herbs have been consumed in its natural form for the major duration of history, very little attention has been paid to the standardization in this industry. It could be possible that the positive effects of ginseng on hyperglycemia may not hold true for all ginseng products due to differences in batches. Sievenpiper, Arnason et al discovered that Asian ginseng showed both null and opposing effects on indices of acute post-prandial plasma glucose and insulin, which contrasted the findings with ginseng, thus showing that different species attribute to different functions (3). As with all chemical components, the metabolized form could generate three possibilities: enhance activity, become toxins, or have no effect. Currently, no studies have taken this factor into consideration. Three main concerns limiting the usage of ginseng include the ubiquitous lack of standardization, in depth mechanism studies, as well as widespread clinical studies (3). Standardization of ginseng components would be the first step to ensuring that there are no unnecessary variations in the data.

\section{Conclusion}

It seems that ginseng and ginsenosides are beneficial for diabetes therapy. Although single ginsenosides have shown to have positive effects, whether a single component or a mixture of components maximizes the therapeutic effect of ginseng on diabetes is still unclear. Many steps have been taken to standardize the usage of ginseng root through isolating specific ginsenosides, which is an effective way to maintain dosages and specificity. It is more than likely that ginseng affects not only the pancreas to increase insulin production but also other tissue to utilize insulin as well as 


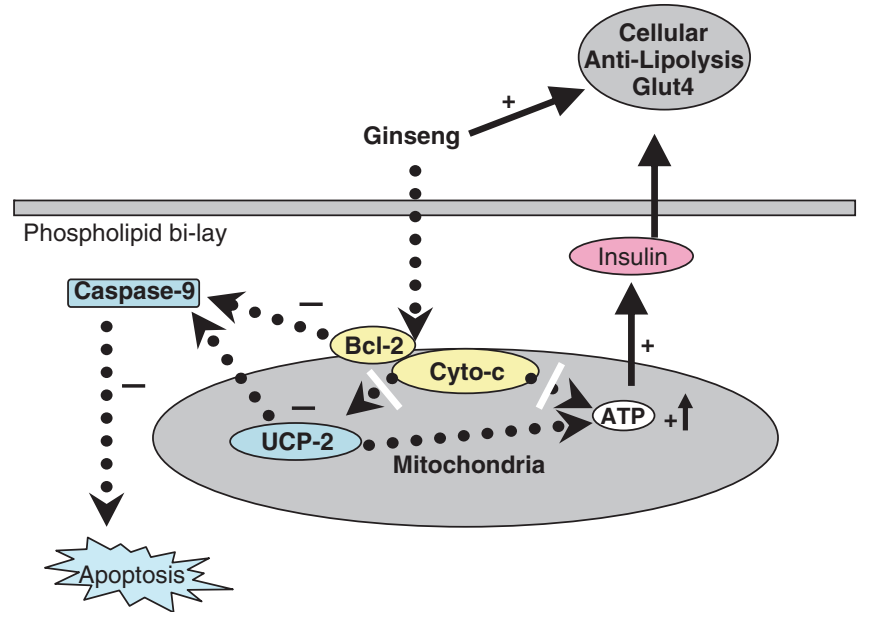

Figure 1. The mechanisms of ginseng activation proposed here in scheme summarizes that the active components of ginseng regulate Uncoupling Protein-2 (UCP-2), which results in a decrease in apoptosis and an increase of ATP production and thus insulin production, which will stimulates cellular glut4 activation to promote metabolism. Ginseng also activates cytochrome-c related $\mathrm{Bcl}-2$ expressing, leading to an inhibition of caspase-9 triggered apoptosis cascade (23). ' +': positive effects '-': negative effects 'solid-line arrow': known actions 'dotted-line arrow': recently discovered actions.

decrease insulin resistance through its various components (15). Ginseng root has been shown to be effective in cell cultures, animal studies, as well as clinical practice. Root extracts and components exhibited anti-hyperglycemic activities and reduced insulin resistance and increased insulin production. Since the mechanisms behind ginseng's effects have not yet been fully discovered, we cannot understand the full extent of its potential. Ginseng root is able to increase insulin production and decrease cell apoptosis in pancreatic $\beta$-cells, which signifies that ginseng affects the pancreas directly. Also, ginseng has been shown to mediate various mechanisms related to muscle and fat tissue such as the GLUT4 pathway (see proposed mechanism of ginseng's activation in Fig. 1). Despite the lack of sufficient widespread clinical, mechanistic studies and standardization for immediate therapeutic uses greatly hinders the possibility of practical applications, current reports of ginseng and ginsenosides point to the possibility of ginseng as a candidate for complementary diabetes therapy.

\section{Future Direction}

In order to effectively apply ginseng on diabetes therapy, three fronts must be expanded. First, standardization of ginseng root has to be taken into consideration as different batches contain different concentrations of ginsenosides. Second, more clinical studies have to be performed to confirm effects of ginseng on both type I and type II diabetic patients. Third, the mechanisms behind ginseng's therapeutic effects have to be examined closely to see the mechanisms which specific components of ginseng act through. Taking these three routes into consideration, the evident yet mysterious effects of ginseng could be elucidated and applied to future therapies.

\section{References}

1. Fujimiya $M$, Kojima $H$, Ichinose $M$, Arai R, Kimura $H$, Kashiwagi A, et al. Fusion of proinsulin-producing bone marrowderived cells with hepatocytes in diabetes. Proc Natl Acad Sci USA 2007; 104:4030-5.

2. Cho WC, Chung WS, Lee SK, Leung AW, Cheng CH, Yue KK. Ginsenoside Re of Panax ginseng possesses significant antioxidant and antihyperlipidemic efficacies in streptozotocin-induced diabetic rats. Eur J Pharmacol 2006;550:173-9.

3. Vuksan V, Stavro MP, Sievenpiper JL, Koo VY, Wong E, BeljanZdravkovic U, et al. American ginseng improves glycemia in individuals with normal glucose tolerance: effect of dose and time escalation. J Am Coll Nutr 2000;19:738-44.

4. Vuksan V, Sievenpiper JL, Wong J, Xu Z, Beljan-Zdravkovic U, Arnason JT, et al. American ginseng (Panax quinquefolius L.) attenuates postprandial glycemia in a time-dependent but not dosedependent manner in healthy individuals. Am $J$ Clin Nutr 2001;73:753-8.

5. Attele AS, Zhou YP, Xie JT, Wu JA, Zhang L, Dey L, et al. Antidiabetic effects of Panax ginseng berry extract and the identification of an effective component. Diabetes 2002;51:1851-8.

6. Vuksan V, Stavro MP, Sievenpiper JL, Beljan-Zdravkovic U, Leiter LA, Josse RG, et al. Similar postprandial glycemic reductions with escalation of dose and administration time of American ginseng in type 2 diabetes. Diabetes Care 2000;23:1221-6.

7. Zhao SJ, Li CY, Qian YC, Luo XP, Zhang X, Wang XS, et al. Induction of hairy roots of Panax ginseng and studies on suitable culture condition of ginseng hairy roots. Sheng Wu Gong Cheng Xue Bao 2004;20:215-20.

8. Susin SA, Lorenzo HK, Zamzami N, Marzo I, Brenner C, Larochette N, et al. Mitochondrial release of caspase-2 and -9 during the apoptotic process. J Exp Med 1999;189:381-94.

9. Yilmaz H, Gursoy A, Sahin M, Guvener Demirag N. Comparison of insulin monotherapy and combination therapy with insulin and metformin or insulin and rosiglitazone or insulin and acarbose in type 2 diabetes. Acta Diabetol 2007;44(4):187-92.

10. Zucchi OL, Moreira S, de Jesus EF, Neto HS, Salvador MJ. Characterization of hypoglycemiant plants by total reflection X-ray fluorescence spectrometry. Biol Trace Elem Res 2005;103:277-90.

11. Dixon P. Ginseng. Gerald Duckworth \& Co. Ltd, London, 1976.

12. Zimmet P. The burden of type 2 diabetes: are we doing enough? Diabetes Metab 2003;29:6S9-18.

13. Mattson MP, Liu D. Mitochondrial potassium channels and uncoupling proteins in synaptic plasticity and neuronal cell death. Biochem Biophys Res Commun 2003;304:539-49.

14. Honeycutt AA, Boyle JP, Broglio KR, Thompson TJ, Hoerger TJ, Geiss LS, et al. A dynamic Markov model for forecasting diabetes prevalence in the United States through 2050. Health Care Manag Sci 2003;6:155-64.

15. Li W, Gu C, Zhang H, Awang DV, Fitzloff JF, Fong HH, et al. Use of high-performance liquid chromatography-tandem mass spectrometry to distinguish Panax ginseng C. A. Meyer (Asian ginseng) and Panax quinquefolius L. (North American ginseng). Anal Chem 2000;72:5417-22.

16. Wan JB, Li SP, Chen JM, Wang YT. Chemical characteristics of three medicinal plants of the Panax genus determined by HPLC-ELSD. J Sep Sci 2007;30:825-32.

17. Xie JT, Wang CZ, Wang AB, Wu J, Basila D, Yuan CS. Antihyperglycemic effects of total ginsenosides from leaves and stem of Panax ginseng. Acta Pharmacol Sin 2005;26:1104-10.

18. Nauck MA, Walberg J, Vethacke A, El-Ouaghlidi A, Senkal M, Holst JJ, et al. Blood glucose control in healthy subject and patients receiving intravenous glucose infusion or total parenteral nutrition using glucagon-like peptide 1. Regul Pept 2004;118:89-97.

19. Jantunen E, Kolho E, Ruutu P, Koukila-Kahkola P, Virolainen M, Juvonen E, et al. Herbal medicines used during the first trimester 
and major congenital malformations: an analysis of data from a pregnancy cohort study. Drug Saf 2006;29:537-48.

20. Lee WK, Kao ST, Liu IM, Cheng JT. Increase of insulin secretion by ginsenoside Rh2 to lower plasma glucose in Wistar rats. Clin Exp Pharmacol Physiol 2006;33:27-32.

21. Liu TP, Liu IM, Cheng JT. Improvement of insulin resistance by panax ginseng in fructose-rich chow-fed rats. Horm Metab Res 2005;37:146-51.

22. Yun SN, Moon SJ, Ko SK, Im BO, Chung SH. Wild ginseng prevents the onset of high-fat diet induced hyperglycemia and obesity in ICR mice. Arch Pharm Res 2004;27:790-6.

23. Luo JZ, Luo L. American ginseng stimulates insulin production and prevents apoptosis through regulation of uncoupling protein-2 in cultured beta cells. Evid Based Complement Alternat Med 2006:3:365-72.

24. Chan CB, MacDonald PE, Saleh MC, Johns DC, Marban E, Wheeler MB. Overexpression of uncoupling protein 2 inhibits glucose-stimulated insulin secretion from rat islets. Diabetes 1999;48:1482-6.

25. Zhang CY, Baffy G, Perret P, Krauss S, Peroni O, Grujic D, et al. Uncoupling protein-2 negatively regulates insulin secretion and is a major link between obesity, beta cell dysfunction, and type 2 diabetes. Cell 2001;105:745-55.

26. Hagen T, Vidal-Puig A. Mitochondrial uncoupling proteins in human physiology and disease. Minerva Med 2002;93:41-57.

27. Rousset S, Alves-Guerra MC, Mozo J, Miroux B, CassardDoulcier AM, Bouillaud F, et al. The biology of mitochondrial uncoupling proteins. Diabetes 2004;53 (Suppl 1):S130-5.

28. Langin D. The role of uncoupling protein 2 in the development of type 2 diabetes. Drugs Today (Barc) 2003;39:287-95.

29. Wang H, Reaves LA, Edens NK. Ginseng extract inhibits lipolysis in rat adipocytes in vitro by activating phosphodiesterase 4. J Nutr 2006;136:337-42.

30. Maedler K, Sergeev P, Ris F, Oberholzer J, Joller-Jemelka HI, Spinas GA, et al. Glucose-induced beta cell production of IL-1beta contributes to glucotoxicity in human pancreatic islets. J Clin Invest 2002;110:851-60.

31. Kim SR, Jo SK, Kim SH. Modification of radiation response in mice by ginsenosides, active components of Panax ginseng. In Vivo 2003; 17:77-81.

32. Luo JZ, Yano N, Luo L. American ginseng stimulates insulin porduction and prevents apoptosis induced by IL-1[beta] in pancreatic [beta] Cells. Diabetes 2003;52:Suppl.1. A354:1534-P.

33. Yu JY, Jin YR, Lee JJ, Chung JH, Noh JY, You SH, et al. Antiplatelet and antithrombotic activities of korean red ginseng. Arch Pharm Res 2006;29:898-903.

34. Chen J, Chen YG, Reifsnyder PC, Schott WH, Lee CH, Osborne $\mathrm{M}$, et al. Altered expression of serum protein in ginsenoside re-treated diabetic rats detected by SELDI-TOF MS. $J$ Ethnopharmacol 2006;108:272-9.

35. Song JY, Han SK, Bae KG, Lim DS, Son SJ, Jung IS, et al. Radioprotective effects of ginsan, an immunomodulator. Radiat Res 2003;159:768-74.

36. Tapsell LC, Hemphill I, Cobiac L, Patch CS, Sullivan DR, Fenech M, et al. Health benefits of herbs and spices: the past, the present, the future. Med $J$ Aust 2006;185:S4-24.

37. Ma L, Qian S, Liang X, Wang L, Woodward JE, Giannoukakis N, et al. Chronic ginseng consumption attenuates age-associated oxidative stress in rats. $J$ Nutr 2003;133:3603-9.
38. Cui J, Chen KJ. American ginseng compound liquor on retardingaging process. Zhong Xi Yi Jie He Za Zhi 1991;11:451,457-60.

39. Baek SH, Im WT, Oh HW, Lee JS, Oh HM, Lee ST. Brevibacillus ginsengisoli sp. nov., a denitrifying bacterium isolated from soil of a ginseng field. Int J Syst Evol Microbiol 2006;56:2665-9.

40. Oshima Y, Sato K, Hikino H. Isolation and hypoglycemic activity of quinquefolans A, B, and C, glycans of Panax quinquefolium roots. J Nat Prod 1987;50:188-90.

41. Vuksan V, Sievenpiper JL, Koo VY, Francis T, BeljanZdravkovic U, Xu Z, et al. American ginseng (Panax quinquefolius L) reduces postprandial glycemia in nondiabetic subjects and subjects with type 2 diabetes mellitus. Arch Intern Med 2000;160:1009-13.

42. Cui Y, Shu XO, Gao YT, Cai H, Tao MH, Zheng W. Association of ginseng use with survival and quality of life among breast cancer patients. Am J Epidemiol 2006;163:645-53.

43. Li Y, Zhang R, Qiao H, Zhang H, Wang Y, Yuan H, et al. Gut and brain effects of American ginseng root on brainstem neuronal activities in rats. Am J Chin Med 1998;26:47-55.

44. Koo BS, Kim YK, Park KS, Chung KH, Kim CH. Attenuating effect of a traditional korean formulation, Paeng-Jo-Yeon-NyeonBaek-Ja-In-Hwan (PJBH), on hydrogen peroxide-induced injury in PC12 cells. Phytother Res 2004;18:488-93.

45. Kitts D, Hu C. Efficacy and safety of ginseng. Public Health Nutr 2000;3:473-85

46. Jeong HG, Pokharel YR, Han EH, Kang KW. Induction of cyclooxygenase-2 by ginsenoside $\mathrm{Rd}$ via activation of CCAAT-enhancer binding proteins and cyclic AMP response binding protein. Biochem Biophys Res Commun 2007;359:51-6.

47. Sung H, Kang SM, Lee MS, Kim TG, Cho YK. Korean red ginseng slows depletion of CD4 T cells in human immunodeficiency virus type 1 -infected patients. Clin Diagn Lab Immunol 2005; 12:497-501.

48. Dasgupta A, Reyes MA. Effect of Brazilian, Indian, Siberian, Asian, and North American ginseng on serum digoxin measurement by immunoassays and binding of digoxin-like immunoreactive components of ginseng with $\mathrm{Fab}$ fragment of antidigoxin antibody (Digibind). Am J Clin Pathol 2005;124:229-36.

49. Salim KN, McEwen BS, Chao HM. Ginsenoside Rb1 regulates ChAT, NGF and trkA mRNA expression in the rat brain. Brain Res Mol Brain Res 1997;47:177-82.

50. Lin JH, Wu LS, Tsai KT, Leu SP, Jeang YF, Hsieh MT. Effects of ginseng on the blood chemistry profile of dexamethasone-treated male rats. Am J Chin Med 1995;23:167-72.

51. Wang LC, Lee TF. Effect of ginseng saponins on exercise performance in non-trained rats. Planta Med 1998;64:130-3.

52. Murphy LL, Lee TJ. Ginseng, sex behavior, and nitric oxide. Ann $N$ $Y$ Acad Sci 2002;962:372-7.

53. Nguyen TT, Matsumoto K, Yamasaki K, Nguyen MD, Nguyen TN, Watanabe H. Crude saponin extracted from Vietnamese ginseng and its major constituent majonoside-R2 attenuate the psychological stress- and foot-shock stress-induced antinociception in mice. Pharmacol Biochem Behav 1995;52:427-32.

54. Luo L, Yano N, Luo JZ. The molecular mechanism of EGF receptor activation in pancreatic beta-cells by thyrotropin-releasing hormone. Am J Physiol Endocrinol Metab 2006;290:889-99.

Received July 5, 2007; accepted August 6, 2007

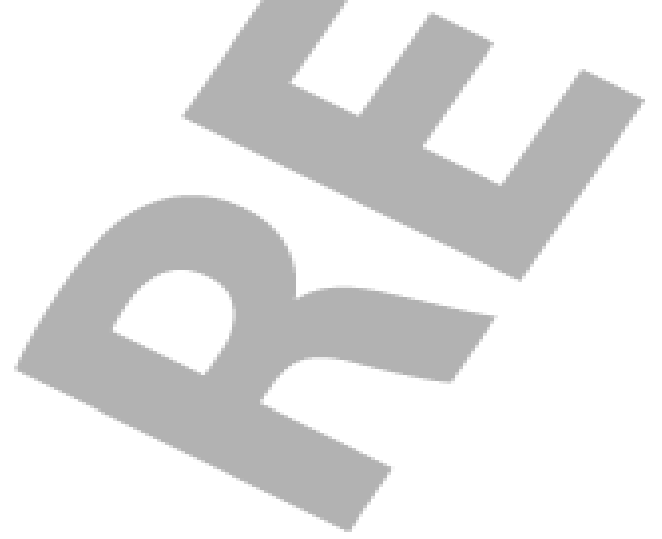




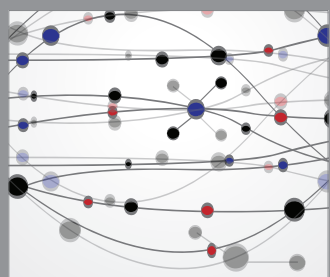

The Scientific World Journal
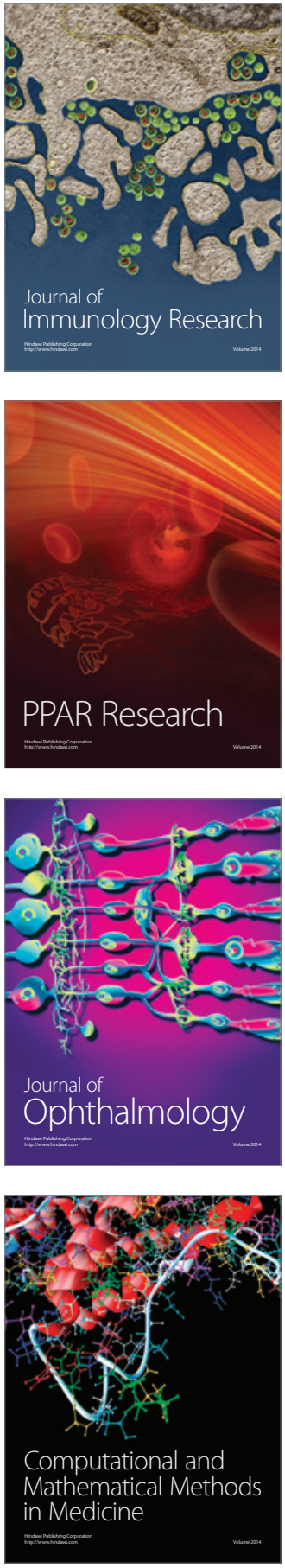

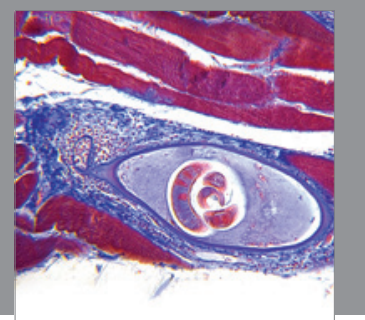

Gastroenterology

Research and Practice
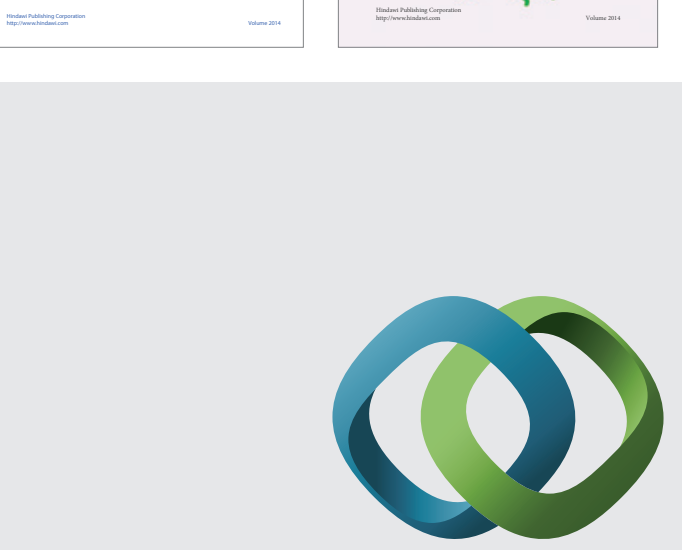

\section{Hindawi}

Submit your manuscripts at

http://www.hindawi.com
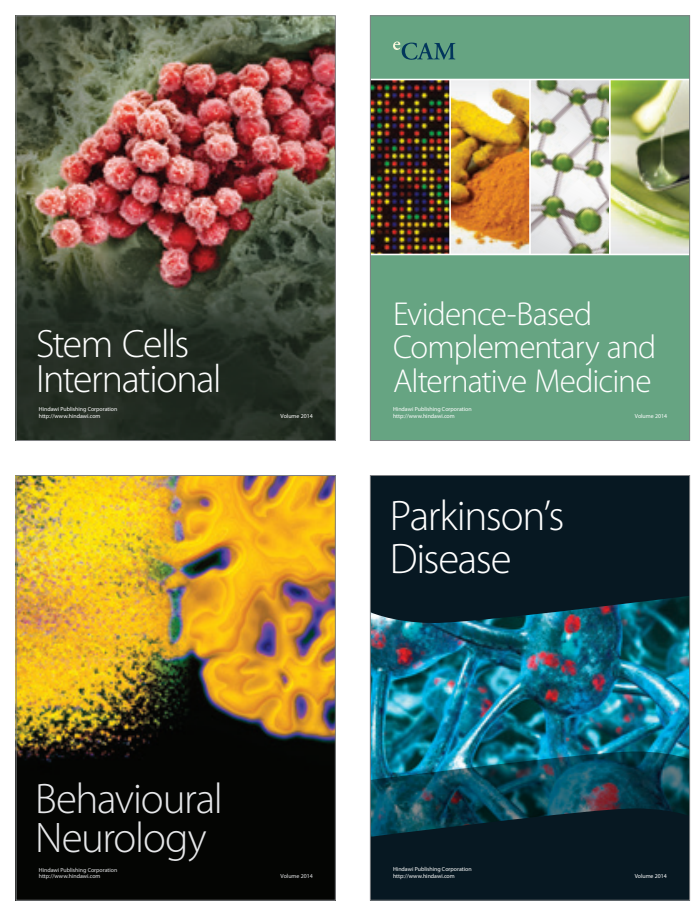

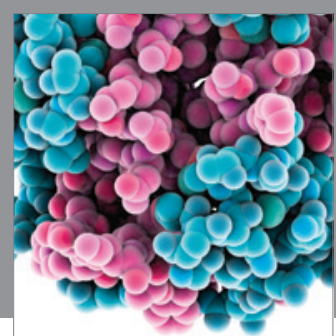

Journal of
Diabetes Research

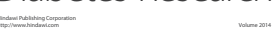

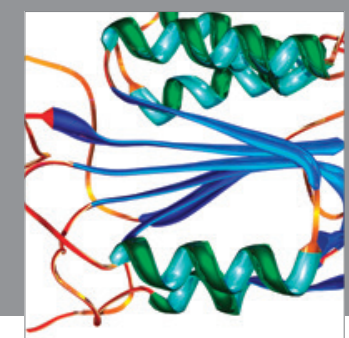

Disease Markers
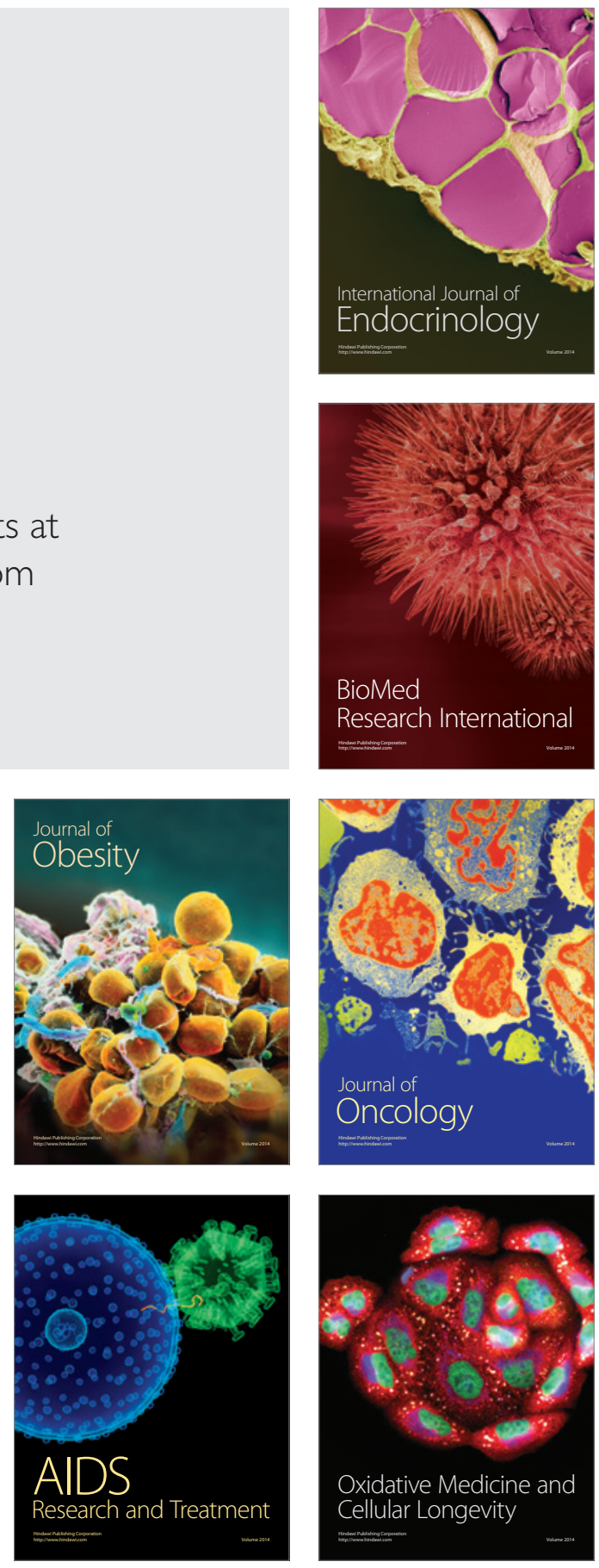